\title{
Preface to the 2008 Edition
}

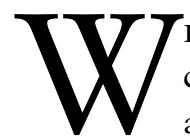

HEN THIS BOOK WAS submitted to my publisher in 2002, it characterized the human rights community as fragmented into a variety of single-issue agendas, and attributed that fragmentation to factors associated with the end of the cold war and accelerating globalization. Even then, one could discern a growing fissure over a set of interrelated policy debates on important global issues. One of those debates was over globalization itself, embraced by one side as opening new space for human rights progress, and denounced by the other as a source of deepening global poverty.

Yet if this first post-cold war human rights debate could be seen retrospectively as a sign of new fault lines, no single event or issue had sufficient force to split the human rights community into two starkly opposed worldviews. That galvanizing issue, sparked by the events of September II, would be what U.S. leaders have described as the "global war on terror." During the five years following the publication of this book in the United States, a second debate now crystallized over whether the United States, the major maestro of globalization, should be seen as the global guardian of human rights or as an empire bent on economic, military, and ideological domination.

As I write this preface in August 2007, it appears that we may be at the dawn of a third debate, born out of the ashes of the American fiasco in Iraq and the resultant Democratic Party takeover of the United States Congress in the November 2006 elections. These events combined to place neo-conservative defenders of unrestrained globalization and democratization, enforceable by U.S. military power, on the defensive. This time, while the global progressive human rights community must continue to confront its old neo-liberal and neo-conservative adversaries, advocates of universal human rights are also taking up the challenge posed by religious (or cultural) fundamentalism in its Islamist and other religious extremist forms.

This foreword offers a perspective on these interacting layers of human rights debate-between globalists and anti-globalists, unilater- 
alists and multilateralists, and between market ideology and religious fundamentalism-suggesting in all three cases that human rights progress will require moving beyond Manichean divisions. I will begin by describing the first two phases of the post-cold war debate over globalization and human rights, then move on to characterize the new debate, offering my view of the basic stance that the human rights community needs to take.

\section{THE FIRST DEBATE:}

\section{GLOBALISTS VERSUS ANTI-GLOBALISTS}

This debate is the one most familiar to those interested in the human rights implications of economic globalization, and much has been discussed in my first edition. For one side, the side with the ear of political elites throughout the developed world, the collapse of the Soviet Union opened the door to the global triumph of a free market economy.

This position has been advanced by mainstream U.S. politicians of both major political parties, who have supported free trade agreements (e.g., NAFTA and the WTO) without insisting on serious labor standards, professing along with leaders like Bill Clinton and Tony Blair that expanded trade will ineluctably help universalize liberal notions of human rights. Those who hold this position are generally confident that economic liberalization, once it takes root in otherwise protectionist or barren economies, will promote, at least in the long run, affluent societies and stable democratic institutions.

By contrast, for the anti-globalist activists of the world social forums, globalization has shaped a new imperial economic regime, one in which the IMF, WTO, the G8, and other international institutions continue to reflect the self-interest of the wealthiest states. For anti-globalists, neoliberalism has produced a sinister reality: one in which labor rights have been undercut and welfare policies scrapped; one in which bait-and-switch immigration policies shaped by elites in the privileged world have intensified the hardships suffered by refugees and immigrants fleeing from poverty, repression, or war; one in which the poorest countries and peoples are getting poorer in both relative and absolute terms; and one in which environmental degradation driven by pollution and deforestation has endangered the livelihood of indigenous peoples.

That leftist critique of globalization has a right-wing variant in developed states, where the primary concern is with the loss of businesses and jobs to low-wage regions. The result has sometimes been strange coalitions between left and right, as when the progressive American activist 
Ralph Nader joined the right-wing, nationalist leader Pat Buchanan in opposing NAFTA and the WTO. Unlike mainstream globalists, who rationalize their human rights strategies in terms of political and security rights, anti-globalists tend to highlight economic, social, and environmental rights. There is, of course, considerable middle ground between the extremes on both sides of this debate, and it is worth considering the outlines of a position around which most human rights supporters might unite.

Can one carve a position between globalists and anti-globalists?

Economic development programs, argued Nobel Prize-winning Indian economist Amartya Sen, should not primarily require the "blood, sweat, and tears" of the poor but should design policies that link economic growth to respect for human freedom and other central tenets of human rights. ${ }^{1}$ Put another way, social, political, civil, and security rights are constitutive parts of development. Sen's insistence that development policies must advance the full spectrum of universal human rights provides criteria for criticizing both sides in the debate between free-traders and anti-globalists. In a sense, he reminds us of the integrated projects of post-World War II reconstruction and the 1948 Universal Declaration of Human Rights.

If Sen's position on sustainable development has gained wider currency in human rights circles, the connection between economic development and sustainable democratic transitions still needs to be strengthened. The underemphasis on economic welfare has its roots in the free market ideology that prevailed in U.S. scholarship and statecraft for decades, from the political science literature on modernization in the I970s and I980s to the Washington Consensus in our current era. That dominant approach to economic development myopically emphasized only two dimensions of rights: the property rights underpinning market economies and the progress toward political freedom that presumably flowed from property rights. Thus, during the cold war, when mass movements of the poor in the Third World insisted on socioeconomic rights, they encountered repression or worse. Once the cold war ended, the prevailing view was that the poorest countries and peoples could be safely ignored. The legacy of neo-liberalism, however, was not the capitalist "end of history" envisioned by the modernization literature, but resurgent, sometimes authoritarian left-leaning regimes in Latin America and the rise of radical Islamist movements in much of the Muslim world. Both types of movements draw support based on their attentiveness to the welfare of the poor, even as both tend to disparage the individual liberties so valued by the promoters of free markets and democratization. 
A viable middle ground between pro- and anti-globalization factions would have to integrate socioeconomic rights into the globalization project. In the face of the high levels of poverty, repression, and conflict afflicting the poorest areas of the world, the success of that enterprise would require both a massive commitment of resources and the construction of practical strategies, tailored to a host of distinctive cases, that effectively address the complex interconnections between political, legal, economic, and security policies. Since an enterprise of that scale was, and remains, unrealistic, it follows that any feasible approach toward those goals would have to be highly selective, focusing on areas small enough to offer hope of tangible results.

For instance, while the United States and other powerful states evidently lack the will and resources to transform every area affected by underdevelopment and oppression, a sustained investment of political and economic resources in selected places might well create new outposts of democracy that could in turn generate further regional economic growth, democratization, and human rights. How would this start? It could take the form of New Deal-style public works projects that relieve unemployment by putting money directly into the hands of ordinary workers. These projects would be designed to build infrastructure for future economic development, such as ports, power plants, and desalinization plants, which would then stimulate public and private investment. Such outposts (in Palestine or even the Sudan, for example) could represent magnets that would then stimulate further regional economic growth, democratization, and human rights.

Empowering women should also be part of a long-term strategy to democratize the Middle East, as well as other regions of less geopolitical interest to the United States and its allies. For instance, providing means for women to earn money (with microlending, literacy efforts, vocational training, etc.) even within the world's poorest and most repressive states can galvanize democratic forces, just as suffragette efforts stimulated democratic impulses in Western civil societies during the late nineteenth century. One needs to free women, and men will be freer to join them in challenging political oppression.

In short, the indivisibility and inalienability of security, political, social, economic, and cultural human rights objectives in all efforts (postwar reconstruction or others) should always be kept in sight. In terms of what I have called the first debate-between advocates and opponents of economic globalization-it is not impossible to conceive a reasoned synthesis 
that enhances economic opportunity while respecting the spectrum of universal rights.

THE SECOND DEBATE:

SPARTACISTS VERSUS CAESARISTS

In the wake of September II, Afghanistan, and Iraq, U.S. foreign policy largely shifted from preoccupation with economic issues to debate over the pursuit of security, in the context of a so-called clash of cultures or civilizations. Whether grievances against the Western architects of globalization were couched in political, economic, or cultural terms, hatred and violence against the West (and particularly the United States) were now rationalized as the inevitable "blowback" resulting from long-standing oppression. Those sentiments in turn unleashed fear of the Muslim world, strengthened demagogic assertions of Western superiority, and made it politically viable to insist on adopting whatever means were allegedly necessary for security.

Confronting both the tragedy of September II and subsequent attacks, and the enormity of the American military and counterterrorism response, the pre-September II preoccupations of the human rights community were now overshadowed by a searing divide over a central question: the human rights implications of America's economic superiority and global military campaign. For many on both sides of this debate, America was viewed in starkly positive or negative terms-either as a crucial entity for the worldwide advance of human rights or as an empire disposed to quash human rights in the pursuit of unlimited power.

I have elsewhere labeled the protagonists in this debate as multilateralists or "Spartacists" and unilateralists or "Caesarists." The Spartacist designation derives from the Thracian Spartacus, the famous leader of a slave rebellion against imperial Rome. Today's Spartacists share an antiauthoritarian, anti-imperialist, and often isolationist view. Most Spartacists are highly critical of unfettered economic globalization, sanctioned by U.S. hegemonic influence in the cultural, political, and military realms. Human suffering, Spartacists argue, is of little concern for U.S. policy makers, who draw attention to it primarily in order to justify intervention against outlaw regimes that dare to challenge the geopolitical or economic interests of the United States and its allies. From this perspective, human rights and humanitarian rhetoric are mere subterfuges to hide imperial self-interest. Not only are their motives disingenuous, the results, 
including interventions against so-called rogue regimes, are likely to make human suffering worse.

On the other hand, the Caesarist worldview-named after the Roman emperor who spread republicanism with ruthless force-maintains that in a world of terrorism, rampant nationalism, civil wars, and proliferating mass destruction weapons, the United States is the only power able to counter international dangers driven by fundamentalist groups or authoritarian regimes. For suffering individuals within weaker states, Caesarists argue, there is no alternative but to gravitate within the orbit of U.S. influence, an outcome that will ultimately deliver economic and human rights benefits. As the United States wages war against anti-democratic forces, it is accepted that trampling on civil rights and international conventions may be necessary means to achieve victory. In the end, however, Caesarist foreign policies claim to extend liberty to all of humanity.

In addition to the divide over the legitimacy of U.S. assertive unilateralism, the issue of how to build a democratic culture in conflict-ridden civil societies also continues to divide the human rights community. To what extent (if any) should the United States (and its Western allies) take responsibility for nation building in the aftermath of allegedly humanitarian interventions? For Caesarists like the historian Niall Ferguson, the United States has been too long in denial of its imperial role and must learn to take seriously its formidable responsibilities in the world. It is the only power, Ferguson maintains (with other like-minded Caesarists), that has the capacity to bring prosperity, peace, and human rights to divided societies in an increasingly hostile world environment. The problem, he argues, is that the United States, unlike its predecessor, Great Britain, has lacked the will to make a long-term commitment to nation building. ${ }^{3}$

To provide insufficient troops to ensure security in the aftermath of the invasions of Afghanistan and Iraq, or to fail to halt gross human rights violations in Liberia, Darfur, and other trouble spots of limited geopolitical importance to the United States, argue Caesarists, will hasten the demise of the American empire. The British Empire sent legions of career civil servants abroad to permanent posts, and the American empire will be short-lived if it fails to emulate that model. In that regard, it is a dangerous sign that the United States has failed to train and dispatch thousands of Arabic-speaking envoys to the Middle East, armed with the requisite skills to move its democratization agenda forward. Caesarists argue that the United States can reclaim its moral authority only by fully committing itself to the full spectrum of nation-building activities.

The prospect of such a U.S. commitment to promoting democratic 
development has, however, been intensely challenged by Spartacists. For Chalmers Johnson, the fact that the United States has spread hundreds of its military bases throughout geopolitically and economically strategic areas of the world is sufficient evidence of its long-standing imperialist nature. ${ }^{4}$ Moreover, that the United States has denied rights specified in the Geneva Convention to Guantanamo prisoners, and has conducted torture of alleged insurgents in Abu Ghraib prison and elsewhere, demonstrates the emptiness of its claim to represent an "empire of liberty." Spartacists add that the United States has used the war on terror to create an elaborate system of surveillance, which has enabled authorities to violate privacy rights, to harass domestic dissidents, and to deport peaceful immigrants as criminals - thereby denying fundamental rights of hospitality to foreigners.

These abuses cumulatively reveal the Janus face of the American empire's purported "good intentions." Spartacists predict that the United States will suffer other cases of blowback like the one experienced on September II, arguing that such attacks are due not to U.S. neglect of global problems, but to the excessive and repressive nature of U.S. global commitments, as the United States supports authoritarian regimes in places like Saudi Arabia or Pakistan whenever it appears to serve its economic or geopolitical interests. That long record of support for "friendly" dictators throughout the cold war has culminated in the current refusal to submit to international institutions such as the International Criminal Court, preferring to withhold evidence that could implicate its own officials during truth commission investigations (in Haiti, El Salvador, Guatemala, Chile, and Chad among other post-authoritarian countries where the United States supported former dictators). ${ }^{5}$ This history, as interpreted by the Spartacists, shows all too well that the United States evades its own standards of justice while calling for democracy and human rights for the rest of the world. Even for those more inclined to acknowledge some measure of good intentions on the part of the United States, it is daunting to recognize that most U.S. military occupations did not lead to the establishment of democratic governments. ${ }^{6}$

While Spartacist-Caesarist debates have raged since the end of the cold war, the escalating confrontation between Spartacists (such as Noam Chomsky, Chalmers Johnson, and Eric Hobsbawm) and Caesarists (such as former U.S. Undersecretary of Defense Paul Wolfowitz and Weekly Standard editor William Kristol), reached a zenith over U.S. policy toward Iraq. Indeed the Iraq debate dramatized the extent to which the division over the U.S. global role had supplanted old ideological differences over 
human rights. While the Caesarist human rights justification for the intervention in Iraq became the linchpin of the American neo-conservative foreign policy platform, it was also supported by many liberal and leftist human rights activists, including journalists and scholars like Michael Ignatieff and Christopher Hitchens, who regarded the approaching war in Iraq as an opportunity-whatever the role of American geopolitical interests-to eradicate a genocidal regime.

In the words of British historian Eric Hobsbawm, the question was "how is the world to confront-contain-the U.S.?" "Some people," Hobsbawm observes, "believing that they have not the power to confront the U.S., prefer to join it. More dangerous are those who hate the ideology behind the Pentagon, but support the U.S. project on the grounds that it will eliminate some local and regional injustices. This may be called an 'imperialism' of human rights." 7 This position mobilized anti-war demonstrations throughout the world, and ironically was joined by the nationalist right, including U.S. politician and commentator Pat Buchanan, leader of France's Front National Jean-Marie Le Pen, and Austrian political leader Georg Haider, who viewed the war in Iraq as "America's war against civilization."

How can the human rights community carve a strategic position between charges of indifference to human rights abuses, to which Spartacists are vulnerable, and accusations of imperialism, associated with Caesarist support for wars against tyrannical regimes? Can one be both a Spartacist and a Caesarist, or can we transcend this divide?

In the absence of a cohesive vision of human rights policy, one can deplore with the Spartacists the long record of human rights abuses in the foreign or domestic policies of all five permanent members of the UN Security Council or within NATO, supporting with Caesarists those instances when military action, even if unilateral, advances the causes of human rights, while accepting the general principle that the United Nations and local, motivated NGOs are preferable mechanisms for resolving humanitarian crises.

If multilateralism offers in principle a better way to deal with humanitarian crises from Bosnia to Iraq, one should recognize that the United Nations has not shown the level of credibility and reliable musculature needed to confront these crises. Needless to say, international legal documents have hardly provided clear guidelines to human rights sympathizers. For instance, while the UN charter decreed the inviolability of sovereign states, the Convention against Genocide permitted the indictment of individuals charged with crimes against humanity, thereby circumventing state 
authority. Further, over the years, the members of the UN Security Council failed to show the level of commitment to human rights envisioned by the founders of the United Nations, and the international body consequently attracted criticism from human rights supporters.

If each humanitarian crisis since the cold war has prompted speculation over how best to redesign new international or multilateral institutions, such institutional questions need to be addressed within the context of today's overriding challenges. In the ordre du jour, it is the confrontation of the forces of market fundamentalism and those of religious fundamentalism that prod us toward an engagement in a third debate.

\section{THE THIRD DEBATE:}

\section{THE CLASH OF FUNDAMENTALISMS}

To a substantial degree, the outcome of the Caesarist-Spartacist debate depended on U.S. behavior and its degree of success in Iraq. As the occupation unfolded, the occupiers' moral failure, exemplified by Abu Ghraib, their heedlessness of the economic needs of ordinary Iraqis, and other manifestations of incompetence by the Bush administration have combined substantially to discredit the Caesarist perspective, as Spartacist Democrats took over Congress, more and more American Republicans felt deserted by their president, and the neo-conservatives descended into internal bickering.

Yet lest we find ourselves celebrating the prospective defeat of imperialism in Iraq, it is worth reminding ourselves that in this case the most dynamic global enemies of George W. Bush are not themselves champions of human rights. Instead, the rising fortunes of the Taliban in Afghanistan, of Ahmadinejad in Iran, of Hezbollah in Lebanon, and of Al Qaeda's numerous branches and allied groups represent the advance of movements that violently repudiate universal human rights, and that embrace forms of mystical, violent irrationalism that bear many of the features of Western historical fascism. If neo-liberalism and then neo-conservatism unwittingly nourished these dark forces, it is surely insufficient to condemn the neocons, celebrate the political downfall of George W. Bush's tragic presidency, and self-righteously withdraw from global engagement. In that sense, the human rights community faces a twofold challenge: confronting the fundamentalism of the market while simultaneously confronting the belligerent fundamentalism of religions.

Leaders of the United States and Great Britain Ronald Reagan and Margaret Thatcher launched what George Soros would later call market 
fundamentalism. Market fundamentalism, according to Soros, is the belief that "competitive markets are always right-or at least they produce results that cannot be improved. The financial markets, in particular are supposed to bring prosperity and stability-the more so, if they are completely free from government interference in their operation and unrestricted in their global reach." But as Soros has pointed out, market fundamentalism, by appealing to the concept of equilibrium, misinterprets the causes of economic growth. "It is not the tendency of equilibrium that creates wealth but the release of energies," he explained. "Wealth creation is a dynamic process. It does not regulate itself, and does not ensure social justice." ${ }^{9}$

Market fundamentalism, one might add, is worse than bad economics. Its ideological prevalence, starting in the 1980 s, reinforced the dark aspects of Western values in the eyes of the world's poor. It was the antithesis of U.S. President Franklin Delano Roosevelt's New Deal call to achieve "freedom from want," replacing it with Gordon Gekko's proclamation to a crowd of stockholders in the movie Wall Street that "greed ... is good."

That distorted formulation of Western values provided a perfect opportunity for Islamist fundamentalists to fill the void left by Western abandonment of the poor. Thus Islamist clerics in the Middle East denounce capitalists as individuals devoted to personal profit, as agents driven by crass materialism and unlimited self-interest. These evils, and/or other conspiratorial designs, are attributed in large measure to Jews, who must be stripped of their enormous power and perhaps destroyed completely. Other religious, ethnic, and national groups are similarly implicated. From these religious fundamentalist perspectives, in their Islamist or other religious forms, democracy is despicable, since it implies that individual preferences can be allowed to interfere with the higher communal purpose, which is fully comprehended only by the leader. Yet for Islamist fundamentalists, it is a moral obligation to meet the basic needs of ordinary people. The fact that such needs were so neglected, first by colonialists and then by corrupt secular elites, has given these fundamentalists a powerful weapon with which to spread their beliefs.

Thus, if laissez-faire is the first commandment of globalization proselytes, fundamentalists draw from religious texts the obligation of economic altruism and along with it, belligerence against infidels as the antidotes to Western greed and decadence. Without overstating the parallel between the dogmatism of market fundamentalism and that of religious fundamentalism, can we carve a new space beyond the Manichean 
world of both fundamentalisms? Can human rights today confront with equal resolve the abuses associated with globalization and the danger posed by anti-Enlightenment forces? That danger, it should be stressed, stems not only from the Muslim world, since Judaism, Christianity, and other religions have also produced anti-Enlightenment fundamentalist movements, which both attack moderate voices within their own religions and join in the general assault on secular thought.

One can only hope that the human rights community can move beyond such schisms generated over globalization or American power, and engage the question of how best to promote a universal agenda that advances freedom, economic justice, and peace. In the interest of stimulating such a "third debate," I think it is reasonable to ask whether a new project, modeled on the post-World War II efforts in Europe (and parts of East Asia), might help provide guidelines. I will conclude by briefly touching on the lessons of those postwar policies for addressing the challenges posed by greed, the arrogance of power, and fundamentalism in our current era of globalization.

The efforts finally to purge Europe of extreme nationalism and fascism after World War II were monumental, including Bretton Woods, the establishment of the UN, the UNESCO Project, the Universal Declaration of Human Rights, and the Marshall Plan, plans that included the creation of a democratic and prosperous Germany. In terms of the domestic societies throughout Western Europe, it was now fully recognized that stability and democratic governance would include a strong representation of the interests of the working class, including "welfare state" standards of health, education, and other social rights that would be extended even to the poorest elements of society. The spectrum of practical steps undertaken within Europe received their most powerful affirmation in the form of the 1948 Universal Declaration of Human Rights. The result was the long-term consolidation of strong civil societies in Europe, growing prosperity, and the adoption of the principles contained in the Universal Declaration (and a host of successor documents) as the basis for legitimate behavior by national governments and the European Community.

Yet despite the proclaimed universality of that United Nations document, the United States and its allies never sought to fashion a "Global New Deal" that would extend the same principles to what was about to become known as the "Third World." Instead, as we all know, the United States assisted nearly every anti-Soviet regime, no matter how repressive, and supported insurgencies against pro-Soviet regimes, no matter who was leading the fight. In the cold war's final superpower confrontation, 
the United States extended that principle, of course, to helping the cause of bin Laden and his fellow mujahideen in Afghanistan.

We have now reaped the harvest of that failure to address belligerent fundamentalism in much of the less developed world. While addressing that failure will require a variety of policies adapted to a host of unique circumstances, I would submit that the essence of a viable strategy for moving forward can be found in the Universal Declaration of Human Rights.

That declaration does not provide a blueprint for policy, but it does offer the most viable framework for defeating totalitarian ideologies. One way of describing that framework is to note that the document crystallized the crucial prerequisites for human dignity, hitherto expressed in different religious and ideological worldviews, and synthesized them in the form of inalienable and indivisible human rights. The implication was that one could not privilege one form of dignity, translated as one cluster of rights, over another form of dignity, protected by another family of rights. Thus security, civil, and political rights could not be favored over social and economic rights, and so forth. Put another way, it is an unacceptable assault upon one's dignity for a person to be forbidden to speak her mind or to participate in political life, or to be forced by hunger to beg for food, or to be subjected to torture or threatened with death. In that sense, the notion that human rights is the protection of some types of fundamental rights but not others or is for some people but not others is simply absurd.

From the Palestinian territories to Iraq to Lebanon, the conservatives of the current American administration have privileged dignity as defined in terms of political rights over social and economic rights, and have inadvertently provided opportunities for fundamentalist groups, which have gained grassroots support thanks largely to their social welfare organizations. Just as Mussolini borrowed that part of socialist doctrine that called for addressing the burdens of ordinary people and the poor, groups like Hamas, Hezbollah, and al-Sadr's Mahdi Army have used the provision of welfare as a foundation for recruitment. To be successful, a longterm strategy for uprooting terror, despair, and poverty cannot afford to pick and choose among categories of human rights.

Building on the spirit and policies of the post-World War II period, an effective global New Deal strategy will need to address the nexus between the global economy, civil society, and radical religious or nationalist ideologies. That will mean transcending the first debate over globalization and human rights, in the sense that the choice will not be between 
neo-liberal globalization and respect for local power structures and cultures, but over what forms of globalization, preferably synchronized with security, sustainable economic development, and political rights, can best advance the spectrum of universal human rights. It will also mean overcoming the second debate's preoccupation with the guilt or innocence of the lone superpower, and will concentrate on assessing which combination of institutional means can most effectively advance a comprehensive human rights agenda.

That does not mean that the human rights community can set aside its unfinished task of taking on the dark sides of globalization and American power. It does propose a shift toward the more forward-looking project of reviving the vision set forth in the Universal Declaration of Human Rights. In doing so, the human rights community achieves enduring victories over the array of adversaries of human rights: from predatory economic actors to abusers of great power to murderous regimes to despotic fundamentalist movements of all ideological stripes.

August 2007

Denver

I. See Amartya Sen, Development as Freedom (New York: Anchor Books, I999).

2. Micheline Ishay, "Debating Globalization and Intervention: Spartacists versus Caesarists," in The Human Rights Reader: Major Political Essays, Speeches, and Documents from Ancient Times to the Present, $2 \mathrm{~d}$ ed. (New York: Routledge, 2007), 465-474.

3. Niall Ferguson, Colossus: The Price of America's Empire (New York: Penguin Press, 2004).

4. Chalmers Johnson, The Sorrows of Empire: Militarism, Secrecy, and the End of the Republic (New York: Metropolitan Books, 2004).

5. Priscilla B. Hayner, Unspeakable Truth: Confronting State Terror and Atrocity (New York: Routledge, 200I), 242-243.

6. Minxin Pei, "Lessons from the Past: The American Record of NationBuilding” (Policy Brief, No. 24, Carnegie Endowment for International Peace, Washington, D.C., April 2003).

7. Eric Hobsbawm, “America's Imperial Delusion," The Guardian, June I 5, 2003.

8. George Soros, “Capitalism's Last Chance," Foreign Policy no. II 3 (Winter I998-I999): 55-66.

9. George Soros, Open Society (New York: Public Affairs, 2000), I44. 
